\title{
High- but not low-intensity light leads to oxidative stress and quality loss of cold-stored baby leaf spinach
}

Marcin Glowacz ${ }^{*}$, Lars M. Mogren², John P.H. Reade, Andrew H. Cobb and James M. Monaghan

Crop and Environment Sciences Department, Harper Adams University, Newport, TF10 8NB, UK

${ }^{I}$ Present address: Natural Resources Institute, University of Greenwich, Chatham, ME4 4TB, UK

${ }^{2}$ Present address: Department of Biosystems and Technology, SLU, Swedish University of Agricultural Sciences, 23053 Alnarp, Sweden

*Corresponding author.

Tel.: +44 (0) 1634 883564, e-mail address: M.M.Glowacz@greenwich.ac.uk

\begin{abstract}
BACKGROUND: Quality management in the fresh produce industry is an important issue. Spinach is exposed to various adverse conditions (e.g. temp, light, etc.) within the supply chain. The experiments were conducted to investigate the effect of light conditions (dark, low intensity light (LL) and high intensity light (HL)) and photoperiod (6 h HL and $18 \mathrm{~h}$ dark) on the quality changes of cold-stored spinach.
\end{abstract}

RESULTS: HL exposure resulted in oxidative stress, causing tissue damage and quality loss evidenced by increased membrane damage and water loss. The content of total ascorbic acid was reduced under HL conditions. On the other hand, storage of spinach under LL conditions gave promising results, as nutritional quality was not reduced, while texture maintenance was improved. No significant differences, with an exception of nutritional quality, were found between spinach leaves stored under continuous (24 h) low intensity light $\left(30-35 \mu \mathrm{mol} \mathrm{m} \mathrm{m}^{-2} \mathrm{~s}^{-1}\right)$ when compared with their counterparts stored under the same light integral over $6 \mathrm{~h}\left(130-140 \mu \mathrm{mol} \mathrm{m} \mathrm{m}^{-2} \mathrm{~s}^{-1}\right)$.

CONCLUSION: LL extended the shelf-life of spinach. The amount of light received by the leaves was the key factor affecting produce quality. Light intensity, however, has to be low enough not to cause excess oxidative stress and lead to accelerated senescence.

Keywords: ascorbic acid, colour evaluation, light intensity, membrane integrity, shelf-life, spinach

\section{INTRODUCTION}

Fresh produce is exposed to various light conditions during its displayed shelf-life and the effects of light exposure on quality changes during the storage of leafy vegetables have been reported for a number of crops including chard (Beta vulgaris L. var. vulgaris), ${ }^{1}$ Chinese kale (Brassica oleracea var. alboglabra), ${ }^{2}$ lettuce (Lactuca sativa L.) ${ }^{3-5}$ and spinach (Spinacia oleracea L.). ${ }^{6}$ 
The shelf-life of spinach is relatively short (7-10 days) and, similar to other leafy vegetables, is influenced by initial quality at harvest ${ }^{7}$ and subsequent storage conditions. ${ }^{8}$ Postharvest senescence is characterized by a number of distinct but interrelated physiological and biochemical processes. These include loss of green colour, tissue breakdown and an increase in reactive oxygen species (ROS).

In most leafy vegetables, green colour is a key characteristic for the consumer and loss of greenness is recognized as a symptom of senescence, ${ }^{9,10}$ reducing their marketability. Tissue breakdown can result in solute leakage from the leaf tissue and an increase in solute leakage has been observed during the storage of baby leaf spinach. ${ }^{11,12}$ Any changes in environmental conditions, e.g. high light stress, may induce production of ROS, ${ }^{13}$ which can be scavenged by leaf antioxidants (e.g. ascorbic acid (AsA)). Thus, if the dose of stress (intensity of light) is high enough to induce antioxidant response, but not too high to cause the tissue damage and accelerate leaf senescence, light exposure may improve nutritional quality of the leaves.

Light exposure has been reported to reduce the solute leakage from lettuce ${ }^{3}$ and spinach leaves ${ }^{14}$ when compared with storage in the dark, suggesting improved leaf resilience. Several authors have also observed reduced rates of AsA loss in spinach stored under continuous low intensity light (20-27 $\mu \mathrm{mol} \mathrm{m}^{-}$ $\left.{ }^{2} \mathrm{~s}^{-1}\right)^{6,15}$ which may be due to higher availability of carbohydrates, precursors of AsA.

The nutritional quality of spinach leaves stored under continuous $(24 \mathrm{~h})$ low intensity $(27 \mu \mathrm{mol}$ $\mathrm{m}^{-2} \mathrm{~s}^{-1}$ ) light at $4{ }^{\circ} \mathrm{C}$ was found to be improved, compared to dark-stored leaves, but the effect of light exposure on visual quality of the leaves was not reported, ${ }^{6}$ whereas enhanced degradation of carotenoids and chlorophylls has been observed by others ${ }^{16}$ in spinach leaves stored under continuous low intensity $\left(27 \mu \mathrm{mol} \mathrm{m} \mathrm{m}^{-2} \mathrm{~s}^{-1}\right)$ light at $4{ }^{\circ} \mathrm{C}$ compared to those stored in the dark.

In other work, reduced visual and nutritional quality has been reported in rocket (Eruca sativa Mill.), chicory (Cichorium intybus L.) and Swiss chard leaves stored under high intensity (150 $\mu \mathrm{mol} \mathrm{\textrm {m } ^ { - 2 }}$ $\mathrm{s}^{-1}$ ) light conditions ( $12 \mathrm{~h}$ light $+12 \mathrm{~h}$ darkness photoperiod) at $4-5{ }^{\circ} \mathrm{C} .{ }^{9}$ It has recently been reported that nutritional, textural and visual quality of fresh-cut lettuce did not differ between samples stored under continuous $(24 \mathrm{~h})$ low intensity $\left(6 \mu \mathrm{mol} \mathrm{m} \mathrm{m}^{-2} \mathrm{~s}^{-1}\right)$ light and photoperiod $(12 \mathrm{~h}$ light $+12 \mathrm{~h}$ darkness $)$ conditions. ${ }^{3}$ This raises the question whether it is the duration of light exposure or intensity of light that has a greater impact on fresh produce quality maintenance during storage.

The inconsistent findings highlight the need to better understand quality changes in response to light exposure during the storage of spinach leaves. This could lead to better quality management within 
the supply chain. The aim of this research was to investigate the effects on postharvest quality measures of cold-stored spinach of (a) light intensity (dark, low intensity and high intensity light), and (b) day length at equal light integral.

\section{MATERIALS AND METHODS}

\section{Plant material and handling}

Baby leaf spinach (Spinacia oleracea L. cv. Toucan) was commercially grown and bagged in $35 \mu \mathrm{m}$ single layer of biaxially oriented polypropylene film (ASP Packaging Ltd, UK), designed for commercial storage of baby leaf salads at PDM Produce Ltd, UK. Spinach was transported to the laboratory $(\sim 15$ minutes) in insulated opaque containers.

In preliminary study, bags with baby leaf spinach were kept for 7 days at $1 \pm 1$ and $6 \pm 1{ }^{\circ} \mathrm{C}$ under

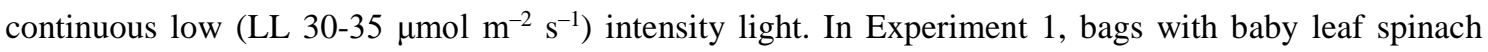
were kept under three different light levels (continuous dark, continuous low (LL 30-35 $\mu \mathrm{mol} \mathrm{m}^{-2} \mathrm{~s}^{-1}$ ) or high (HL 130-140 $\mu \mathrm{mol} \mathrm{m}^{-2} \mathrm{~s}^{-1}$ ) intensity light) at $1.0 \pm 1.0^{\circ} \mathrm{C}$ for 7 days. In Experiment 2, bags were kept under continuous $(24 \mathrm{~h}) \mathrm{LL}$ or photoperiod $(6 \mathrm{~h} \mathrm{HL}+18 \mathrm{~h}$ darkness $)$ conditions. These light levels correspond with those studied by others ${ }^{2,4-6,9,15}$ The actual observed temperature, in both experiments, was in the range $1.1-1.3^{\circ} \mathrm{C}$, as recorded with Tinytag ${ }^{\mathrm{TM}}$ temperature loggers (Gemini Data Loggers Ltd, UK). All measurements (gas composition, solute leakage, total ascorbic acid, total carotenoids and chlorophylls content, and leaf colour) were taken on the harvesting day and then when samples were collected from storage.

\section{Gas composition analyses}

Gas composition $\left(\mathrm{O}_{2}\right.$ and $\left.\mathrm{CO}_{2}\right)$ in individual bags was monitored using a MAP test 3050 analyser (HITECH Instruments, UK). The volume of $0.20 \mathrm{ml}$ of gas from each package was analysed when bags were removed from storage.

\section{Solute leakage determination}

Solute leakage was determined according to the method described previously. ${ }^{17}$ Approximately $5.0 \mathrm{~g}$ of spinach leaves, with an even distribution of size and stage of development, was transferred from each bag to $500 \mathrm{ml}$ beakers, to which $200 \mathrm{ml}$ of deionised water was added. This step was followed by $3 \mathrm{~h}$ incubation at ambient temperature $\left(20.0 \pm 2.0{ }^{\circ} \mathrm{C}\right)$. Conductivity was subsequently measured in micro Siemens $(\mu \mathrm{S})$ using a Jenway model 4510 conductivity meter (Bibby Scientific Ltd, UK) and calculated per g FW. Samples were removed from the bathing solution and slowly frozen at $-20.0 \pm 2.0{ }^{\circ} \mathrm{C}$ to ensure 
maximum disruption of membranes prior to re-measuring the conductivity using the same method as for fresh tissue. Solute leakage was then expressed as a percentage of maximum conductivity.

\section{Total ascorbic acid extraction and determination}

Ascorbic acid was extracted and analysed using a method described previously. ${ }^{18}$ Spinach leaves $(50.0 \pm 2.0 \mathrm{~g})$ were chopped with a sharp knife. Spinach tissue $(5.00 \pm 0.01 \mathrm{~g})$ was placed in a $50 \mathrm{ml}$ tube to which $25 \mathrm{ml}$ of cold $\left(4^{\circ} \mathrm{C}\right) 1.5 \%\left(15 \mathrm{~g} / \mathrm{l} \mathrm{w} / \mathrm{v}\right.$ in $\left.\mathrm{H}_{2} \mathrm{O}\right)$ meta-phosphoric acid $\left(\mathrm{HPO}_{3}\right)$ (Acros Organics, UK) was added. Samples were immediately homogenized with a Silverson SL2 mixer (Silverson Machines Ltd, UK), and then put on ice. Processed samples were transferred to a freezer $\left(-70{ }^{\circ} \mathrm{C}\right)$ for storage. Prior to analysis, spinach extracts were thawed in lukewarm water, in the dark. The extracts were centrifuged at 3,480 x g for 40 min at $4{ }^{\circ} \mathrm{C}$. Supernatants were filtered with Sep Pak filters (Phenomenex, UK) and 1.5 $\mathrm{ml}$ was collected in Eppendorf tubes. Following filtration, extracts were microfuged at 9,300 x $\mathrm{g}$ for 5 min. Finally, $500 \mu \mathrm{l}$ were transferred into HPLC vials for AsA determination. Another $500 \mu \mathrm{l}$ were transferred to new $1.5 \mathrm{ml}$ Eppendorf tubes and mixed thoroughly using a vortex, with an equal volume of $1 \%\left(11 \mathrm{mg} / \mathrm{ml} \mathrm{w} / \mathrm{v}\right.$ in $\left.1 \mathrm{M} \mathrm{K}_{2} \mathrm{HPO}_{4} / \mathrm{H}_{2} \mathrm{O}(1 / 4, \mathrm{v} / \mathrm{v})\right)$ DTT solution (DL-Dithiothreitol)(Fisher Scientific, UK). The DTT solution samples were left for $40 \mathrm{~min}$ at room temperature $\left(20.0 \pm 2.0{ }^{\circ} \mathrm{C}\right)$, and then microfuged at 9,300 x g for $5 \mathrm{~min}$. Samples were transferred into HPLC vials for total AsA (AsA + DHA) determination.

Samples were analysed using an Agilent 1100 HPLC (Agilent, UK) with a Luna $5 \mu \mathrm{m} \mathrm{NH2} 100$ A column $(250 \mathrm{~mm} \times 4.6 \mathrm{~mm})\left(\right.$ Phenomenex, UK) at a flow rate of $1.2 \mathrm{ml} \mathrm{min}^{-1}$ and pressure in the range of 70-80 bars. The mobile phase consisted of $25 \% 15 \mathrm{mmol} \mathrm{l}^{-1}\left(1.725 \mathrm{~g} / \mathrm{l} \mathrm{w} / \mathrm{v}\right.$ in $\left.\mathrm{H}_{2} \mathrm{O}\right)$ of $\mathrm{NH}_{4} \mathrm{H}_{2} \mathrm{PO}_{4}$ (mono ammonium phosphate) (Sigma-Aldrich, UK) and $75 \%$ of acetonitrile (Fisher Scientific, UK); pH was adjusted to 3.9 with $1 \mathrm{M}$ ortho-phosphoric acid $\left(\mathrm{H}_{3} \mathrm{PO}_{4}\right)$ (Acros Organics, UK). Freshly prepared eluent was degassed for $30 \mathrm{~min}$ in an ultrasonic bath. The concentration of AsA and DHA was determined according to external AsA standards (Acros Organics, UK) of 10, 25, 50 and 100 ppm. The volume of $20 \mu \mathrm{l}$ of each sample was analysed in this process.

\section{Chlorophyll and total carotenoid determination}

The concentration of chlorophylls and total carotenoids was determined using the method described previously, ${ }^{19}$ with modifications. ${ }^{20}$ A portion $(50.0 \pm 1.0 \mathrm{~g})$ of the leaf material was freeze-dried and ground into powder. The volume of $0.50 \pm 0.01 \mathrm{~g}$ was transferred to a $50 \mathrm{ml}$ tube and $40 \mathrm{ml}$ of $80 \%$ (acetone/ $\left.\mathrm{H}_{2} \mathrm{O}(4 / 1, \mathrm{v} / \mathrm{v})\right)$ acetone (Fisher Scientific, UK) containing $1 \mathrm{mg}$ of magnesium carbonate (Fisons 
Scientific Apparatus Ltd, UK), to stabilize pigments, and $0.5 \mathrm{mg}$ of sodium bisulfite (Sigma-Aldrich, UK)

- drying agent, was added. Each tube was covered with a lid, and left for $24 \mathrm{~h}$ in the dark for the extraction to proceed. Extracts were subsequently centrifuged at $15,000 \mathrm{x}$ g for $15 \mathrm{~min}$. Approximately $4.5 \mathrm{ml}$ of supernatant was transferred to a quartz cuvette and the absorbance of extracts was measured spectrophotometrically at 480,645, 663 and $710 \mathrm{~nm}$. The concentrations of chlorophyll $a, b$ and total carotenoids were determined using spectrophotometer readings in equations given by Lichtenthaler and Wellburn: ${ }^{19}$

Equations used:

Chlorophyll $a$

$\operatorname{chl} a\left(\mu \mathrm{g} \mathrm{ml}{ }^{-1}\right)=[12.21 \times(\mathrm{A} 663-\mathrm{A} 710)]-[2.81 \times(\mathrm{A} 645-\mathrm{A} 710)]$

Chlorophyll $b$

$\operatorname{chl} b\left(\mu \mathrm{g} \mathrm{ml}^{-1}\right)=[20.13 \times(\mathrm{A} 645-\mathrm{A} 710)]-[5.03 \times(\mathrm{A} 663-\mathrm{A} 710)]$

$\underline{\text { Total carotenoids }}$

Total carotenoids $\left(\mu \mathrm{g} \mathrm{ml}^{-1}\right)=\left([1000 \times(\mathrm{A} 480-\mathrm{A} 710)]-\left[3.27 \times \mathrm{chl} a\left(\mu \mathrm{g} \mathrm{ml}^{-1}\right)\right]-\left[104 \times \mathrm{chl} b\left(\mu \mathrm{g} \mathrm{ml}^{-1}\right)\right]\right) / 200$ Leaf colour measurements

Leaf colour was measured with a Minolta CR-300 chroma meter (Minolta, Japan) calibrated using the manufacturer's standard white plate. Leaf colour changes were quantified for 10 leaves from each sample in the $L^{*}, a^{*}$ and $b^{*}$ colour space. ${ }^{21}$

\section{Dry matter content}

For dry matter determination aluminium trays were weighed and filled with approximately $12 \mathrm{~g}$ of chopped spinach leaves. The trays were transferred to an oven $\left(75 \pm 2{ }^{\circ} \mathrm{C}\right)$ for $48 \mathrm{~h}$, and then placed in $105 \pm 2{ }^{\circ} \mathrm{C}$ for $60 \mathrm{~min}$; the weight of the aluminium trays with fresh and dried spinach tissue was quantified and moisture content was determined. The results are expressed on both fresh (FW) and dry weight (DW) basis to avoid the outcome that would only be reflecting differences related to changes in the water content of the leaves.

\section{Statistical analyses}

Experiments 1 and 2 were each repeated with very similar results, verified by the Bartlett's homogeneity test. In both experiments, data are presented as mean values from two repeated trials that were used as blocks. Data were subjected to analysis of variance (ANOVA) to identify the treatments that had significant effect on quality changes during the storage of baby leaf spinach. Tukey's test was used to 
allow the comparisons between individual treatments. All statistical analyses were performed using GenStat $13^{\text {th }}$ Edition software..$^{22}$

\section{RESULTS AND DISCUSSION}

\section{Preliminary study}

Storage temperature is the most important factor affecting the quality of leafy vegetables, ${ }^{18,23-27}$ since all determinants of quality, i.e. the loss of texture, development of off-odours and off-flavours, visual quality (leaf colour, chlorophyll degradation and/or tissue browning), changes in AsA, carotenoids and flavonoids are temperature dependent. The recommended temperature for storage of fresh-cut vegetables and salad bags is $1-3{ }^{\circ} \mathrm{C} .{ }^{28}$ It is becoming more common in the UK, for leafy vegetable industry to use the temperature of $1{ }^{\circ} \mathrm{C}$ and temperatures of $0.7-1.3{ }^{\circ} \mathrm{C}$ have been reported by others ${ }^{28}$ during the storage period inside refrigerated retail displays. Furthermore, since numbers of authors have previously stored leafy vegetables at this low temperature ${ }^{2,29-35}$ it was of interest, to compare quality changes during the storage of baby leaf spinach at 1 and $6{ }^{\circ} \mathrm{C}$.

Spinach leaves have relatively high respiration rate, and it has been reported by others ${ }^{26,36}$ that respiration rate of spinach increases with increasing temperature of storage from 1 to $12{ }^{\circ} \mathrm{C}^{26}$ and from 4 to $8{ }^{\circ} \mathrm{C} .{ }^{36}$ Enhanced respiration often results in the loss of texture. Luo et al. ${ }^{26}$ observed higher respiration rate and increased solute leakage in spinach samples stored at $12{ }^{\circ} \mathrm{C}$ when compared with their counterparts stored at $1{ }^{\circ} \mathrm{C}$. In our study, solute leakage from spinach leaves stored at $6{ }^{\circ} \mathrm{C}$ was significantly $(P<0.001)$ higher (about $40 \%$ increase) when compared with those stored at $1{ }^{\circ} \mathrm{C}$. This finding suggests that even a small difference in storage temperature may have a major impact on quality maintenance during the storage of baby leaf spinach.

The effect of storage temperature of 2 and $10^{\circ} \mathrm{C}$ on AsA content in harvested spinach has been investigated by Bergquist et al. ${ }^{18}$ who found a smaller loss of AsA at the lower storage temperature. In our study, the AsA content $\left(241.1 \mathrm{mg} \mathrm{kg}^{-1} \mathrm{FW}\right.$ - initial value) remained relatively stable during 7 days storage period with no significant difference between samples kept at $1\left(217.2 \mathrm{mg} \mathrm{kg}^{-1} \mathrm{FW}\right)$ and $6{ }^{\circ} \mathrm{C}$ (207.6 $\left.\mathrm{mg} \mathrm{kg}^{-1} \mathrm{FW}\right)$ under LL $\left(30-35 \mu \mathrm{mol} \mathrm{m} \mathrm{m}^{-2} \mathrm{~s}^{-1}\right)$ conditions. The content of AsA was also relatively stable, as reported by Lester et al. ${ }^{6}$ in spinach leaves stored under continuous light $\left(27 \mu \mathrm{mol} \mathrm{m}^{-2} \mathrm{~s}^{-1}\right)$ at 4 ${ }^{\circ} \mathrm{C}$.

Chlorophyll $a$ and chlorophyll $b$ content was significantly higher in spinach leaves stored at $1{ }^{\circ} \mathrm{C}$ (chl $a$ : $538.8 \mathrm{mg} \mathrm{kg}^{-1} \mathrm{FW}$; chl $b: 127.8 \mathrm{mg} \mathrm{kg}-1$ FW) when compared with the samples stored at $6{ }^{\circ} \mathrm{C}(\mathrm{chl}$ 
a: $479.4 \mathrm{mg} \mathrm{kg}^{-1} \mathrm{FW}$; chl $b$ : $105.0 \mathrm{mg} \mathrm{kg}^{-1} \mathrm{FW}$ ). Pandrangi and $\mathrm{LaBorde}^{24}$ observed a decrease in chlorophyll content after 2 days of storage with storage temperature being increased from 2 to $10{ }^{\circ} \mathrm{C}$, whereas Baldassarre et al. ${ }^{36}$ did not observe significant differences between 4 and $8{ }^{\circ} \mathrm{C}$ until 9 days of storage. Overall, the loss of chlorophyll is accelerated with increasing temperature of storage, which is related to higher activity of enzymes involved in chlorophyll degradation ${ }^{37}$ and enhanced membrane disruption, because chlorophyllase, enzyme involved in chlorophyll degradation, is separated from its substrate and does not come into contact with it until membrane integrity is reduced.

Total carotenoid content remained relatively stable during storage and was only slightly but not significantly higher in spinach leaves stored at $1{ }^{\circ} \mathrm{C}\left(117.0 \mathrm{mg} \mathrm{kg}^{-1} \mathrm{FW}\right)$ when compared with samples stored at $6{ }^{\circ} \mathrm{C}\left(111.6 \mathrm{mg} \mathrm{kg}^{-1} \mathrm{FW}\right)$, which is in agreement with others ${ }^{6,18}$ who found carotenoids to be relatively stable during the storage of spinach.

Leaf lightness value did not change much throughout 7 day storage period at $1{ }^{\circ} \mathrm{C}$ and no difference was observed between spinach leaves stored at 1 and $6{ }^{\circ} \mathrm{C}$. No difference was also observed in leaf yellowness after 3 days of storage, however, after 7 days of storage spinach leaves stored at $6{ }^{\circ} \mathrm{C}$ $\left(b^{*}=30.19\right)$ were significantly $(P<0.001)$ more yellow than those stored at $1{ }^{\circ} \mathrm{C}\left(b^{*}=26.45\right)$.

A significant decline in visual quality of spinach leaves was previously found with increasing storage temperature from 4 to $20{ }^{\circ} \mathrm{C},{ }^{24}$ from 2 to $10{ }^{\circ} \mathrm{C}^{18}$ and from 1 to $12{ }^{\circ} \mathrm{C} .{ }^{26}$ Visual quality of spinach, on the other hand, was well maintained during 6 days of storage at $7{ }^{\circ} \mathrm{C},{ }^{12,38}$ but then it declined. In agreement with those studies, in our study visual quality was found to be reduced after 7 days of storage at $6{ }^{\circ} \mathrm{C}$.

The loss of textural and visual quality was found to be accelerated with increasing temperature of storage from 1 to $6{ }^{\circ} \mathrm{C}$. Thus, temperature of $1{ }^{\circ} \mathrm{C}$ was selected to subsequently study the effects of light exposure on quality changes during the storage of baby leaf spinach.

\section{Experiment 1}

\section{Gas composition}

Gas composition inside the bags with spinach is the consequence of a balance between photosynthesis and respiration and the gas permeability of the packaging film. A relative increase in respiration, as indicated by higher $\mathrm{CO}_{2}$ could indicate tissue deterioration. In agreement with other studies on spinach stored in the dark at $5{ }^{\circ} \mathrm{C}^{11,39}$ and $7{ }^{\circ} \mathrm{C},{ }^{38}$ a decrease in $\mathrm{O}_{2}$ with simultaneous increase in $\mathrm{CO}_{2}$ concentration was found in the bags stored at $1{ }^{\circ} \mathrm{C}$ in the dark. The concentration of $\mathrm{CO}_{2}$ in those bags 
increased from $0.0 \%$ to $2.5 \%$ and $3.1 \%$ after 3 and 7 days of storage, respectively. Light conditions during storage had a significant $(P<0.001)$ effect on gas composition inside the bags with spinach leaves. In the case of spinach leaves stored at $1{ }^{\circ} \mathrm{C}$ under light (LL, HL) conditions, $\mathrm{O}_{2}$ concentration remained high and $\mathrm{CO}_{2}$ was not detected during the 7 day storage period, suggesting that respiration was compensated by photosynthetic activity of the leaves ${ }^{15}$ and/or that film permeability to $\mathrm{O}_{2}$ and $\mathrm{CO}_{2}$ met physiological requirements of baby leaf spinach. ${ }^{40}$

\section{Solute leakage}

After 3 days of storage, solute leakage decreased significantly $(P<0.05)$ from $4.6 \%$ (initial value) to $3.5 \%$ in samples stored under LL at $1{ }^{\circ} \mathrm{C}$ (Figure 1), whereas no significant change was observed in samples stored at $1{ }^{\circ} \mathrm{C}$ either in the dark $(4.3 \%)$ or under HL (4.4\%) conditions. After 7 days, solute leakage from spinach leaves kept under LL conditions remained significantly lower, compared to the leaves stored in the dark or under HL conditions.

Under continuous low intensity light conditions, solute leakage was found to be reduced compared to dark-stored leaves. The same response has been observed in other studies. ${ }^{3,14}$ It has been shown that more stomata remain open in light-stored kale $^{2}$ and Romaine lettuce ${ }^{3}$ when compared with their dark-stored counterparts. This could lead to increased water loss leading to a loss of turgor and thus a decrease in textural quality of the leaf. ${ }^{17,30}$ The stability of cell walls ${ }^{7}$ was probably better maintained in spinach leaves that received certain amount of light during storage. The low light level would have allowed photosynthesis and, spinach leaves would be able to increase the pool of carbohydrates,${ }^{15}$ thus supplying substrates for respiration, whereas in the continuous dark treatment leaf membrane lipids may be used in respiration, ${ }^{41}$ weakening cell integrity.

No benefit of light exposure during storage was noticed when light level/amount was too high. An explanation for this observation is that HL led to excess oxidative stress that caused tissue damage ${ }^{42}$ which is often associated with increased lipid peroxidation. ${ }^{43}$ Lipid peroxidation is another reflection of stress-induced damage at the cellular level and increased solute leakage indicates the severity of the damage caused by ROS. The loss of texture may also be related to solubilisation of cell wall pectin and loss of carbohydrates as a result of enhanced respiration. These modifications reduce cell wall strength and cell to cell adhesion, leading to leaf softening. ${ }^{44}$ Possible mechanism may also relate to tissue dehydration. ${ }^{30}$ 


\section{Total ascorbic acid content}

The content of AsA in spinach leaves decreased during the 7 day storage period. A significant $(P<0.001)$ decrease in AsA content from $4.12 \mathrm{mg} \mathrm{g}^{-1} \mathrm{DW}$ (251.4 mg kg-1 FW) (initial value) to $3.26 \mathrm{mg} \mathrm{g}^{-1} \mathrm{DW}$ (231.5 mg kg-1 FW) was already observed after 3 days in samples stored under HL conditions, while no change took place in those stored in the dark or under LL conditions, where AsA content was 4.14 (256.7 $\left.\mathrm{mg} \mathrm{kg}^{-1} \mathrm{FW}\right)$ and $4.16 \mathrm{mg} \mathrm{g}^{-1} \mathrm{DW}\left(253.8 \mathrm{mg} \mathrm{kg}^{-1} \mathrm{FW}\right)$, respectively. After 7 days, AsA content decreased with increasing light intensity but only when expressed on DW basis (Table 1). When expresses on FW basis, the AsA content in spinach stored under HL (219.0 $\left.\mathrm{mg} \mathrm{kg}^{-1} \mathrm{FW}\right)$ was not significantly different from those stored in the dark $\left(239.9 \mathrm{mg} \mathrm{kg}^{-1} \mathrm{FW}\right)$. Different outcome on FW and DW basis was due to significantly higher dry matter content found in spinach leaves stored under HL (7.2\%), when compared with their counterparts stored in the dark (6.4\%) and under LL (6.3\%), which is associated with higher water loss. This would be in agreement with several authors ${ }^{1-3}$ who have previously reported significantly higher water loss during the storage of chard, ${ }^{1}$ Chinese kale $^{2}$ and lettuce, ${ }^{3}$ as a result of light exposure, when compared with their dark-stored counterparts.

DHA content in spinach increased during the 7 day storage period. The lowest DHA content was observed in spinach leaves stored at $1{ }^{\circ} \mathrm{C}$ under HL conditions. After 3 days of storage, DHA content in these samples was $0.08 \mathrm{mg} \mathrm{g}^{-1} \mathrm{DW}\left(5.7 \mathrm{mg} \mathrm{kg}^{-1} \mathrm{FW}\right)$ and was significantly lower than in their counterparts stored in the dark $\left(0.25 \mathrm{mg} \mathrm{g}^{-1} \mathrm{DW}\left(15.5 \mathrm{mg} \mathrm{kg}^{-1} \mathrm{FW}\right)\right)$ or under LL conditions $\left(0.31 \mathrm{mg} \mathrm{g}^{-1}\right.$ DW (18.9 $\left.\left.\mathrm{mg} \mathrm{kg}^{-1} \mathrm{FW}\right)\right)$. After 7 days of storage, the highest DHA content of $1.04 \mathrm{mg} \mathrm{g}^{-1} \mathrm{DW}(65.5 \mathrm{mg}$ $\mathrm{kg}^{-1} \mathrm{FW}$ ) was found in the samples stored under LL conditions. The same pattern was observed when DHA content was expressed on DW basis (Table 1).

In the case of total AsA content, the pattern was similar to the one observed for AsA. No significant difference was observed between spinach leaves stored in the dark (283.4 $\left.\mathrm{mg} \mathrm{kg}^{-1} \mathrm{FW}\right)$ and under LL conditions (265.9 $\left.\mathrm{mg} \mathrm{kg}^{-1} \mathrm{FW}\right)$. Total AsA content in those samples was significantly $(P<0.001)$ higher than in their counterparts stored under HL conditions $\left(237.0 \mathrm{mg} \mathrm{kg}^{-1} \mathrm{FW}\right)$.

There was no significant difference in the content of AsA, DHA and total AsA between samples stored in the dark and under LL conditions after 3 and 7 days of storage. This is in contrast with other studies $^{6,15}$ that reported better retention of AsA in light-stored samples. The response during storage, however, may vary due to cultivar and maturity, ${ }^{6,45}$ and seasonal - pre-harvest conditions, i.e. the amount of light received during growth, which will differ between seasons. ${ }^{45,46}$ 
Better retention of AsA in spinach leaves stored under dark and LL conditions, when compared with those stored under HL conditions, could be explained by either its biosynthesis or reduced turnover due to higher activity of AsA-glutathione cycle that is responsible for regeneration of AsA. ${ }^{13,47} \mathrm{~A}$ significant decrease in AsA and total AsA content found under HL conditions, suggests that under excess oxidative stress, nutritional quality of spinach leaves is reduced. Exposure of spinach leaves to HL probably led to increase in ROS, which then needed to be scavenged by AsA. The level of ROS produced in response to HL may exceed the capacity of cells to scavenge them, leading to photo-oxidative damage. ${ }^{48}$ Thus, the rapid change in AsA content under HL conditions is not surprising, as it is a key antioxidant in leaf tissue. ${ }^{13,49}$ Its role is to scavenge ROS that are produced in excess under stress conditions.

Plant cells have a capability to reduce the damage caused by ROS using antioxidant enzymes superoxide dismutase (SOD), ascorbate peroxidase (APX), glutathione reductase (GR), catalase (CAT) and metabolites, including AsA and glutathione (GSH), to transform ROS to less toxic compounds, e.g. water, using AsA as an electron donor. ${ }^{13,50}$ In the reaction catalysed by APX, AsA is changed into DHA. It has recently been reported ${ }^{51}$ that during the storage of spinach leaves decrease in AsA content was indeed associated with increased activity of APX. The loss of AsA, on the other hand, was found to be reduced when the activity of dehydroascorbate reductase (DHAR), an enzyme responsible for converting DHA to AsA, was increased. ${ }^{51}$

AsA acts not only as an antioxidant itself but plays a role in photo-protection, being a cofactor for violaxanthin deepoxidase in the xanthophyll cycle.52 The xanthophyll cycle, where under HL violaxanthin is transformed to zeaxanthin, is responsible for non-photochemical quenching of ROS, which are mainly generated in the reaction centres of photosystem I and II. The xanthophyll cycle is induced by changes in $\mathrm{pH}$ across thylakoid membranes, which result from exposure to HL. ${ }^{48}$

Decrease in AsA was compensated by the increase in DHA in spinach leaves stored in the dark or under LL but not under HL conditions, which suggests that a certain amount of AsA was lost. The content of DHA is often used as an indication of stress in the leaf: ${ }^{13}$ however, care is needed as DHA can undergo further conversion, e.g. an irreversible hydrolysis to 2, 3-diketogulonic acid. ${ }^{53}$

\section{Chlorophyll and total carotenoid content}

The content of chlorophyll $a$ and $b$ increased after 3 days of storage under HL (chl $a$ : $1.64 \mathrm{~g} \mathrm{~kg}^{-1} \mathrm{FW}$; chl $b: 428 \mathrm{mg} \mathrm{kg}^{-1} \mathrm{FW}$ ) conditions, and was then significantly higher when compared with the samples stored 
in the dark (chl $a: 1.23 \mathrm{~g} \mathrm{~kg}^{-1} \mathrm{FW}$; chl $b: 327 \mathrm{mg} \mathrm{kg}^{-1} \mathrm{FW}$ ) or under LL (chl $a: 1.10 \mathrm{~g} \mathrm{~kg}^{-1} \mathrm{FW}$; $\operatorname{chl} b: 307$ mg kg-1 FW) conditions. After 7 days chlorophylls content declined in the samples stored under light (both LL (chl $a$ : $1.01 \mathrm{~g} \mathrm{~kg}^{-1} \mathrm{FW}$; chl $b: 277 \mathrm{mg} \mathrm{kg}^{-1} \mathrm{FW}$ ) and HL (chl $a: 1.34 \mathrm{~g} \mathrm{~kg}^{-1} \mathrm{FW}$; chl $b: 345 \mathrm{mg}$ $\mathrm{kg}^{-1} \mathrm{FW}$ ) conditions, while its content did not change significantly in those stored in the dark (chl $a: 1.29$ $\mathrm{g} \mathrm{kg}^{-1} \mathrm{FW}$; chl $b$ : $337 \mathrm{mg} \mathrm{kg}^{-1} \mathrm{FW}$ ). This resulted in the lowest chlorophyll content (on FW basis) being observed in the spinach samples stored under LL conditions, with no significant difference between samples stored in the dark and under HL. This was, however, not the case, when values were expressed on DW basis (Table 2), where chlorophyll content decreased in light-stored samples when compared with their dark-stored counterparts. This is in agreement with others ${ }^{9,16}$ who demonstrated that chlorophyll degradation was enhanced by light exposure during the storage of spinach $^{16}$ and rocket $^{9}$ leaves, respectively. Similar to changes in AsA, different outcome on FW and DW basis reflects changes in dry matter content associated with water loss.

After 3 days of storage total carotenoid content significantly increased in spinach leaves stored at $1{ }^{\circ} \mathrm{C}$ under $\mathrm{HL}$ conditions $\left(397.7 \mathrm{mg} \mathrm{kg}^{-1} \mathrm{FW}\right)$, while it remained relatively stable in the samples stored in the dark (306.9 $\left.\mathrm{mg} \mathrm{kg}^{-1} \mathrm{FW}\right)$ or under LL conditions (299.0 $\left.\mathrm{mg} \mathrm{kg}^{-1} \mathrm{FW}\right)$. After 7 days total carotenoid content increased in spinach leaves stored in the dark (367.9 $\left.\mathrm{mg} \mathrm{kg}^{-1} \mathrm{FW}\right)$ and under LL conditions (335.2 $\mathrm{mg} \mathrm{kg}^{-1} \mathrm{FW}$ ) and was no longer significantly different from the samples stored under HL conditions (387.6 $\left.\mathrm{mg} \mathrm{kg}^{-1} \mathrm{FW}\right)$. The same pattern was observed when total carotenoid content was expressed on DW basis (Table 2).

Total carotenoid content was found to be relatively stable under all storage conditions tested. This is in agreement with others ${ }^{6,18}$ who reported carotenoids to be relatively stable or even increase during the storage of spinach. This may be explained by their important role in photosynthesis and protection of chlorophylls and chloroplasts from photo-oxidative damage. ${ }^{54}$ Furthermore, as already mentioned above, carotenoids may be transformed from one to another (xanthophyll cycle) in response to changes in light intensity.

\section{Leaf colour}

Similar to others ${ }^{39}$ who did not observe any changes in colour of spinach leaves stored for 13 days at $5{ }^{\circ} \mathrm{C}$ in the dark, no changes in the leaf colour was observed, in this work, in dark-stored spinach leaves (Table 3). With increasing light intensity spinach leaves became significantly lighter $\left(L^{*}\right)$ and more yellow $\left(b^{*}\right)$, while no significant difference was observed in greenness $\left(a^{*}\right)$ value throughout the storage period (Table 
3). No significant difference in leaf yellowness was observed between spinach leaves stored in the dark and under LL conditions; however leaves stored under HL conditions were significantly more yellow than their dark-stored counterparts already after 3 days of storage. It is not surprising that from all leaf colour characteristics $\left(L^{*}, a^{*}\right.$ and $\left.b^{*}\right)$ the strongest change was reported for leaf yellowness, as the process of leaf yellowing is the main issue associated with the loss of visual quality during the storage of spinach leaves. Leaves may become more yellow due to changes in the chlorophyll: carotenoids ratio, however, it is difficult to find a clear correlation between plant pigment content and leaf colour changes. Other groups $^{18,24}$ also could not find a correlation between pigment content and visual quality of spinach leaves. This suggests that leaf colour may be influenced not only by pigment content but also by changes in leaf texture and water content. ${ }^{18}$ Plant pigments are not homogenously distributed within the leaf, so there might be a mismatch between the readings.

\section{Experiment 2}

\section{Effect of photoperiod}

No significant differences between the quality of spinach leaves stored under continuous (24 h) low intensity $\left(30-35 \mu \mathrm{mol} \mathrm{m} \mathrm{m}^{-2} \mathrm{~s}^{-1}\right)$ light and photoperiod $\left(6 \mathrm{~h}\right.$ high intensity $\left(130-140 \mu \mathrm{mol} \mathrm{m}^{-2} \mathrm{~s}^{-1}\right)$ light/ dark) was observed in gas composition, solute leakage, DHA, chlorophylls, total carotenoids and leaf colour characteristics).

Similar to Experiment 1, in case of both spinach leaves stored at $1{ }^{\circ} \mathrm{C}$ under continuous $(24 \mathrm{~h})$ low intensity (30-35 $\left.\mu \mathrm{mol} \mathrm{m} \mathrm{m}^{-2} \mathrm{~s}^{-1}\right)$ light and those under photoperiod conditions, $\mathrm{O}_{2}$ concentration remained high and $\mathrm{CO}_{2}$ was not detected during the 10 day storage period, suggesting that respiration was compensated by photosynthetic activity of the leaves. ${ }^{15}$ No significant difference between the treatments (continuous (24 h) low intensity light and photoperiod) was also observed in terms of solute leakage from spinach leaves.

Even though the content of plant pigment in spinach leaves from Experiment 2 was lower when compared with leaves used in Experiment 1, light conditions during storage - continuous LL or photoperiod (HL/dark) - had no significant effect. Leaf colour characteristics were also unaffected (Table 4). The difference in visual quality of spinach leaves used in both experiments can be explained by different conditions during the growing season; ${ }^{45,46}$ leaves used in Experiment 1 and 2 were harvested in October 2011 and July 2012, respectively. 
On the other hand, the concentration of AsA and total AsA was significantly lower in spinach samples stored under photoperiod conditions compared to samples stored under continuous low intensity light (Figure 2). This suggests that even relatively short exposure to high intensity light may lead to an excess oxidative stress that accelerates AsA degradation, thus reducing nutritional quality of spinach leaves.

\section{CONCLUSIONS}

This research has shown that nutritional content of the leaves (AsA, DHA, total AsA, and total carotenoids) was preserved during the storage of spinach under continuous $(24 \mathrm{~h}) \mathrm{LL}$ conditions. Furthermore, tissue integrity measured as solute leakage, which indicates membrane damage/texture loss, was reduced in these samples and development of $\mathrm{CO}_{2}$ in the bags was prevented by photosynthetic activity of the leaves. Increasing in light intensity from $30-35$ to $130-140 \mu \mathrm{mol} \mathrm{m} \mathrm{m}^{-2} \mathrm{~s}^{-1}$ resulted in a decline in AsA, DHA and total AsA, and increased solute leakage from spinach leaves, while having no effect on plant pigment content and leaf colour characteristics after 7 days of storage at $1{ }^{\circ} \mathrm{C}$.

The findings from this research suggest that both light intensity and light integral have an effect on spinach quality during postharvest storage. No significant differences, with an exception of nutritional quality, were found between spinach leaves stored under continuous low intensity light compared to their counterparts stored under the same light integral over $6 \mathrm{~h}$, i.e. it is the amount of light received by the leaves that has a greater impact on produce quality. Light intensity has to be low enough not to cause excess oxidative stress, which would lead to accelerated senescence. Future studies should be carried out to identify the threshold in light intensity that does not compromise spinach quality, so that recommendations, in terms of adequate duration and light intensity, can be made to retailers and the supply chain.

\section{ACKNOWLEDGEMENTS}

We thank Harper Adams University for financial support and members of Princess Margaret Science Laboratories and Crop and Environment Research Centre for their technical assistance.

\section{REFERENCES}

1. Sanz S, Olarte C, Ayala F, Echavarri JF, The response to lighting of minimally processed chard: Influence on its shelf life. J Sci Food Agric 88:1622-1631 (2008). 
2. Noichinda S, Bodhipadma K, Mahamontri C, Narongruk T, Ketsa S, Light during storage prevents loss of ascorbic acid, and increases glucose and fructose levels in Chinese kale (Brassica oleracea var. alboglabra). Postharvest Biol Tec 44:312-315 (2007).

3. Martinez-Sanchez A, Tudela JA, Luna C, Allende A, Gil MI, Low oxygen levels and light exposure affect quality of fresh-cut Romaine lettuce. Postharvest Biol Tec 59:34-42 (2011).

4. Zhan L, Li Y, Hu J, Pang L, Fan H, Browning inhibition and quality preservation of fresh-cut romaine lettuce exposed to high intensity light. Innov Food Sci Emerg Technol 14:70-76 (2012).

5. Zhan L, Hub J, Ai Z, Pang L, Li Y, Zhu M, Light exposure during storage preserving soluble sugar and L-ascorbic acid content of minimally processed romaine lettuce (Lactuca sativa $\mathrm{L}$. var. longifolia). Food Chem 136:273-278 (2013).

6. Lester GE, Makus DJ, Hodges DM, Relationship between fresh-packaged spinach leaves exposed to continuous light or dark and bioactive contents: effects of cultivar, leaf size, and storage duration. J Agric Food Chem 58:2980-2987 (2010).

7. Wagstaff C, Clarkson GJJ, Zhang FZ, Rothwell SD, Fry SC, Taylor G, Dixon MS, Modification of cell wall properties in lettuce improves shelf life. J Exp Bot 61:1239-1248 (2010).

8. Piagentini AM, Mendez JC, Guemes DR, Pirovani ME, Modeling changes of sensory attributes for individual and mixed fresh-cut leafy vegetables. Postharvest Biol Tec 38:202-212 (2005).

9. Ferrante A, Incrocci L, Maggini R, Serra G, Tognoni F, Colour changes of fresh-cut leafy vegetables during storage. J Food Agric Environ 2:40-44 (2004).

10. Koukounaras A, Siomos AS, Sfakiotakis E, Impact of heat treatment on ethylene production and yellowing of modified atmosphere packaged rocket leaves. Postharvest Biol Tec 54:172-176 (2009).

11. Allende A, Luo YG, McEvoy JL, Artes F, Wang CY, Microbial and quality changes in minimally processed baby spinach leaves stored under super atmospheric oxygen and modified atmosphere conditions. Postharvest Biol Tec 33:51-59 (2004).

12. Medina MS, Tudela JA, Marín A, Allende A, Gil MI, Short postharvest storage under low relative humidity improves quality and shelf life of minimally processed baby spinach (Spinacia oleracea L.). Postharvest Biol Tec 67:1-9 (2012).

13. Mittler R, Oxidative stress, antioxidants and stress tolerance. Trends Plant Sci 7:405-410 (2002). 
14. Kar RK, Choudhuri MA, Effects of light and spermine on senescence of Hydrilla and spinach leaves. Plant Physiol 80:1030-1033 (1986).

15. Toledo MEA, Ueda Y, Imahori Y, Ayaki M, L-ascorbic acid metabolism in spinach (Spinacia oleracea L.) during postharvest storage in light and dark. Postharvest Biol Tec 28:47-57 (2003).

16. Kopas-Lane LM, Warthesen JJ, Carotenoid photostability in raw spinach and carrots during cold storage. J Food Sci 60:773-776 (1995).

17. Wagstaff C, Clarkson GJJ, Rothwell SD, Page A, Taylor G, Dixon MS, Characterisation of cell death in bagged baby salad leaves. Postharvest Biol Tec 46:150-159 (2007).

18. Bergquist SAM, Gertsson UE, Olsson ME, Influence of growth stage and postharvest storage on ascorbic acid and carotenoid content and visual quality of baby spinach (Spinacia oleracea L.). $J$ Sci Food Agric 86:346-355 (2006).

19. Lichtenthaler HK, Wellburn AR, Determinations of total carotenoids and chlorophylls $a$ and $b$ of leaf extracts in different solvents. Biochem Soc T 11:591-592 (1983).

20. Edwards EJ, Saint RS, Cobb AH, Is there a link between greening and light-enhanced glycoalkaloid accumulation in potato (Solanum tuberosum L) tubers? J Sci Food Agric 76:327333 (1998).

21. Abbott JA, Quality measurement of fruits and vegetables. Postharvest Biol Tec 15:207-225 (1999).

22. Payne RW, Harding SA, Murray DA, Soutar DM, Baird DB, Glaser AI, Channing IC, GenStat $13^{\text {th }}$ Edition, Reference Manual (2010).

23. Jacxsens L, Devlieghere F, Debevere J, Temperature dependence of shelf-life as affected by microbial proliferation and sensory quality of equilibrium modified atmosphere packaged fresh produce. Postharvest Biol Tec 26:59-73 (2002).

24. Pandrangi S, LaBorde LF, Retention of folate, carotenoids, and other quality characteristics in commercially packaged fresh spinach. J Food Sci 69:C702-C707 (2004).

25. Martinez-Sanchez A, Allende A, Cortes-Galera Y, Gil MI, Respiration rate response of four baby leaf Brassica species to cutting at harvest and fresh-cut washing. Postharvest Biol Tec 47:382-388 (2008). 
26. Luo YG, He Q, McEvoy JL, Conway WS, Fate of Escherichia coli O157:H7 in the presence of indigenous microorganisms on commercially packaged baby spinach, as impacted by storage temperature and time. J Food Protect 72:2038-2045 (2009).

27. Spinardi A, Ferrante A, Effect of storage temperature on quality changes of minimally processed baby lettuce. J Food Agric Environ 10:38-42 (2012).

28. Nunes MCN, Emond JP, Rauth M, Dea S, Chau KV, Environmental conditions encountered during typical consumer retail display affect fruit and vegetable quality and waste. Postharvest Biol Tec 51:232-241 (2009).

29. DuPont MS, Mondin Z, Williamson G, Price KR, Effect of variety, processing, and storage on the flavonoid glycoside content and composition of lettuce and endive. J Agric Food Chem 48:3957-3964 (2000).

30. Aguero MV, Barg MV, Yommi A, Camelo A, Roura SI, Postharvest changes in water status and chlorophyll content of lettuce (Lactuca sativa L.) and their relationship with overall visual quality. J Food Sci 73:S47-S55 (2008).

31. Aguero MV, Ponce AG, Moreira MR, Roura SI, Lettuce quality loss under conditions that favor the wilting phenomenon. Postharvest Biol Tec 59:124-131 (2011).

32. Barg M, Aguero MV, Yommi A, Roura SI, Evolution of plant water status indices during butterhead lettuce growth and its impact on post-storage quality. J Sci Food Agric 89:422-429 (2009).

33. Hagen SF, Borge GIA, Solhaug KA, Bengtsson GB, Effect of cold storage and harvest date on bioactive compounds in curly kale (Brassica oleracea L. var. acephala). Postharvest Biol Tec 51:36-42 (2009).

34. Harbaum-Piayda B, Walter B, Bengtsson GB, Hubbermann EM, Bilger W, Schwarz K, Influence of pre-harvest UV-B irradiation and normal or controlled atmosphere storage on flavonoid and hydroxycinnamic acid contents of pak choi (Brassica campestris L. ssp chinensis var. communis). Postharvest Biol Tec 56:202-208 (2010).

35. Kobori CN, Huber LS, Sarantopoulos CIGL, Rodriguez-Amaya DB, Behavior of flavonols and carotenoids of minimally processed kale leaves during storage in passive Modified Atmosphere Packaging. J Food Sci 76:H31-H37 (2011). 
36. Baldassarre V, Cabassi G, Ferrante A, Use of chlorophyll $a$ fluorescence for evaluating the quality of leafy vegetables. Aust J Crop Sci 5:735-741 (2011).

37. Hortensteiner S, Chlorophyll degradation during senescence. Annu Rev Plant Biol 57:55-77 (2006).

38. Tudela JA, Marín A, Garrido Y, Cantwell M, Medina-Martínez MS, Gil MI, Off-odour development in modified atmosphere packaged baby spinach is an unresolved problem. Postharvest Biol Tec 75:75-85 (2013).

39. Conte A, Conversa G, Scrocco C, Brescia I, Laverse J, Elia A, Del Nobile MA, Influence of growing periods on the quality of baby spinach leaves at harvest and during storage as minimally processed produce. Postharvest Biol Tec 50:190-196 (2008).

40. Martinez JA, Chiesa A, Tovar F, Artes F, Respiration rate and ethylene production of fresh cut lettuce as affected by cutting grade. Agric Food Sci 14:354-361 (2005).

41. Buchanan-Wollaston V, The molecular biology of leaf senescence. J Exp Bot 48:181-199 (1997).

42. Foyer $\mathrm{CH}$, Shigeoka $\mathrm{S}$, Understanding oxidative stress and antioxidant functions to enhance photosynthesis. Plant Physiol 155:93-100 (2011).

43. Hodges DM, Forney CF, Postharvest ascorbate metabolism in two cultivars of spinach differing in their senescence rates. J Am SocHortic Sci 128:930-935 (2003).

44. Clarkson GJJ, O'Byrne EE, Rothwell SD, Taylor G, Identifying traits to improve postharvest processability in baby leaf salad. Postharvest Biol Tec 30:287-298 (2003).

45. Lester GE, Makus DJ, Hodges DM, Jifon JL, Summer (subarctic) versus winter (subtropic) production affects spinach (Spinacia oleracea L.) leaf bionutrients: vitamins (C, E, folate, $\mathrm{K}_{1}$, provitamin A), lutein, phenolics, and antioxidants. J Agric Food Chem 61: 7019-7027 (2013).

46. Barbieri G, Bottino A, Di Stasio E, Vallone S, Maggio A, Proline and light as quality enhancers of rocket (Eruca sativa Miller) grown under saline conditions. Sci Hortic 128:393-400 (2011).

47. Blokhina O, Virolainen E, Fagerstedt KV, Antioxidants, oxidative damage and oxygen deprivation stress: a review. Ann Bot 91:179-194 (2003).

48. Asada K, Production and scavenging of reactive oxygen species in chloroplasts and their functions. Plant Physiol 141:391-396 (2006). 
49. Conklin PL, Recent advances in the role and biosynthesis of ascorbic acid in plants. Plant Cell Environ 24:383-394 (2001).

50. Foyer $\mathrm{CH}$, Noctor $\mathrm{G}$, Redox regulation in photosynthetic organisms: signaling, acclimation, and practical implications. Antioxid Redox Signaling 11:861-905 (2009).

51. Cocetta G, Baldassarre V, Spinardi A, Ferrante A, Effect of cutting on ascorbic acid oxidation and recycling in fresh-cutbaby spinach (Spinacia oleracea L.) leaves. Postharvest Biol Tec 88:816 (2014).

52. Eskling M, Arvidsson PO, Akerlund HE, The xanthophyll cycle, its regulation and components. Physiol Plantarum 100:806-816 (1997).

53. Davey MW, Van Montagu M, Inze D, Sanmartin M, Kanellis A, Smirnoff N, Benzie IJJ, Strain JJ, Favell D, Fletcher J, Plant L-ascorbic acid: chemistry, function, metabolism, bioavailability and effects of processing. J Sci Food Agric 80:825-860 (2000).

54. Demmig-Adams B, Gilmore AM, Adams WW, Carotenoids.3. In vivo functions of carotenoids in higher plants. Faseb J 10:403-412 (1996). 